Original Contribution

\title{
STUDY OF THE FACTORS, SYMPTOMS AND CAUSES OF CRISIS IN CERTAIN BUSINESS ORGANIZATIONS IN VELIKO TARNOVO
}

\author{
D. Yordanova* \\ Faculty of Economics,"St. Cyril and St. Methodius" University of Veliko Tarnovo, Bulgaria
}

\begin{abstract}
Organizational crises can be prevented and managed if the risk factors, symptoms, and causes of their occurrence are known. The factors of the financial crisis are external and internal. Symptoms appear in the financial and economic indicators, and their trends reflect the functioning and development of the organization. They are just an external manifestation of the beginning of a crisis situation, but the reasons for its occurrence lead to the crisis itself. The development of the events under the "risk - causes - crisis situation - unwanted consequences" is a logical process of realization of the potential danger of a crisis. The subject of the study is the factors, the symptoms and the occurrence of crises in the organizations. The aim of the study is to justify the relation management of organizational crises and the reasons for their occurrence.

Methods of research: questionnaire, the study of the relations management of organizational crises and the reasons for their occurrence, analysis of the results, conclusions.

Scope of the survey: The survey was conducted in 2018. It included five companies from the construction sector in Veliko Tarnovo.

Results: The results show that the main factors for crisis occurring, in the first place, according to the surveyed companies, are the organizational faults and in the second place is the technical fault. Their views on the barriers to the more efficient management of organizational crises are united. As such, they indicate mainly the limited budget.
\end{abstract}

Key words: factors, symptoms, causes, crises, business organizations, Veliko Tarnovo

\section{INTRODUCTION}

Organizational crises can be prevented and managed if the risk factors, symptoms, and causes of their occurrence are known.

Much of the risk factors and conditions in the organization are anthropogenic. These are all processes, phenomena and conditions resulting from the creative or destructive human activity in nature, macro and microsphere, in the individual enterprise and beyond. (1)

According to G. Georgiev (2), the financial and accounting analysis reveals and measures the impact of the factors that contributed to the final results with a view to revealing the reserves, making more use of resources and increasing economic efficiency.

\footnotetext{
*Correspondence to: Chief Assistant Daniela Yordanova, PhD, Department of Economic management, Faculty of Economics, "St. Cyril and St. Methodius" University of Veliko Tarnovo, Bulgaria (1, Arch. Georgi Kozarev str., Veliko Tarnovo 5000),yordanova_didka@abv.bg
}

The cost-effectiveness assessment can be integrated into a generic accounting analysis model using different cost-effectiveness techniques: cost-effectiveness, cost-utility and cost-benefit. Such a model allows to characterize different aspects of the organization's activity and could be built on the example of a particular organization in the public or private sector. (3)

Good knowledge management leads to the anticipation of crisis factors and the development of targeted policies. The factors of the financial crisis are external and internal. The following factors are related to the external ones:

- general economic downturn in national income, growth in inflation, slowing payment turnover, unstable tax system, lowering the real income of the population, rising unemployment, etc.;

- market - reduction of capacity in the domestic market, strengthening of the monopoly, significant reduction of demand, reduction of 
the active stock market, volatile currencies, high interest rates on credit resources, insufficient market information, etc.

Internal factors include:

- Operational - inefficient marketing and structure of running costs, low level of utilization and large wear and tear of fixed assets, insufficient variety of product range and inefficient production management;

- Investments -an ineffective portfolio of shares or bonds, significant excess of investment resources, non-fulfillment of the planned volume of profits, inefficient investment management;

- financial - inefficient strategies and asset structure, a high share of borrowed capital, growth of receivables, and inefficient financial management.

Symptoms appear in the financial and economic indicators, and their trends reflect the functioning and development of the organization. Tesa is only an external manifestation of the beginning of a crisis situation, but the reasons for its occurrence lead to the crisis itself. Symptoms of crisis may be the first signs of negative trends, the sustainability of these trends, business conflicts, the development of financial problems, and other factors.

There is a relation between the risks and causes of the crisis situations: the risk is a consequence of a certain cause, which in turn is a consequence of another cause, and so on. The development of events under the "risk causes - crisis situation - unwanted consequences" scheme is a logical process of realization of the potential danger of a crisis and of real damages (consequences). (4)

Crises should be evaluated not only for the symptoms but also for their causes - whether external or internal. External causes of crises occur outside an organization (state of the economy, state of the industry to which the organization belongs). The internal ones are those in the organization itself (leadership incompetence, slowing down the organization, uncompetitive market position, personnel management problems, expensive production, neglect of the financial function, inefficient information system, etc.). $(5,6,7)$

These reasons should be treated as helpful tools in the organization's analysis. They recognize that each organization, along with its processes, products, history, and employees, is a kind of system and should therefore be studied as such.

Although external causes play a key role in crises, in many cases they occur within the organization itself. Internal causes can be successfully eliminated by internal adjustments.

In the scientific literature, there are no few reasons leading to organizational crises.

According to M. Paunov (8), some of the most common causes of organizational stress are related to ignoring the adverse effects on profit due to overly aggressive attempts to gain market share.

P. Mayer (9) classifies the reasons for: conjunctural - depending on the circumstances and structural - created by disturbing the equilibrium in the structural elements of the system.

In their publications, S. Hamilton and A. Micklethwait (10) state that the underlying causes of crises and failure in organizations should be grouped into the following categories: ineffective strategic decisions; rapid growth and reckless purchases; management incompetence; greed, arrogance and desire for power; insufficient internal control at all levels.

Research indicates that insolvency in organizations is caused by managerial incompetence. $(11,12,13)$

According to D. Bibeault (14), it is born in $80 \%$ of the cases and in the rest is the result of the state of the economy.

G. Ivanova (15) considers that the management problems are due to: insufficient knowledge and experience, difficult adaptation to changes, insufficient control, etc.

According to H. Raikov (16), the circumstances that create a real possibility for a crisis in the organization are: he has recently experienced a crisis; is experiencing financial difficulties; it is newly formed; an atmosphere of stress and high turnover of employees; unfair competition.

J. Atali (17) highlights some basic reasons for a crisis-dependent organization. According to him, the reasons are: mistakes in the understanding and analysis of the market situation, inability to manage effectively, bad 
management, poor organizational culture, lack of self-respect and respect for the organization. In her research, D. Andreeva (18) points out that the reasons for a crisis in the organization are found in the analysis of the financial statements.

How can organizations become vulnerable to crises and become insolvent?

Research on this issue provokes a number of ideas that will help managers understand why and how an apparently effective organization can become vulnerable to a crisis. The main approach outlined in the PAS 200: 2011 (19) standard is to understand the organization as a system of social and technical dimensions that are complex and interdependent. Each failure in the organization includes a network of related factors - social and technical. This requires the manager to recognize the following:

- mistakes in the organization, its operations and governance, which are the basis of the failure;

- finding an unsuccessful element of the business process, which requires a deeper consideration;

- poor decision-making and lack of preparedness to cope with the stress that crises are causing.

At present, the problems of insolvency and the optimal financial condition of firms are becoming more and more relevant. The state of insolvency is characterized by an inability to meet commitments such as overpayments on assets. This is the last and the worst stage of the financial crisis. (20)

This article explores the relations between organizational crises and the reasons for their occurrence in Veliko Tarnovo. (21)

"In general, the companies from the Veliko Tarnovo region, much more compared to the national level, use good managerial practices. This propensity can be seen in a positive way, as it talks about the openness of business executives from the region to the positive aspects of managing other businesses and their desire to improve their own management. This circumstance suggests the desire of corporate managers to increase the competitiveness of the companies they manage." (22)

\section{METHODOLOGY OF THE RESEARCH}

To investigate the relations management of organizational crises and the reasons for their occurrence, five companies were interviewed in Veliko Tarnovo and three surveys were presented. They are directed at managers of construction companies in Veliko Tarnovo regarding their opinion on organizational crisis management.

\section{RESULTS AND DISCUSSION}

As a result of the Survey 1. Management of organizational crises and the reasons for them, the following results were obtained: most of the surveyed companies $(80 \%)$ indicated that they were in a state of an insufficient budget. For less of them, the current state is related to obsolete equipment and equipment (20\% of respondents).

On the question "Are the risks related to the company's operational activity?", The following responses were received: the relative share of companies that believe that the risks are related to the operating activity is $60 \%$ and $40 \%$ think this is not the case.

On the question "What mechanisms do you do to resolve the current situation?", The following responses were received: all companies $(100 \%)$ are of the opinion that they are undertaking economic mechanisms. The relative share of respondents who say that they take organizational mechanisms to solve current problems (80\%) is high and high.

To the question "What are the main factors that you attach to a crisis in the company?" All companies point out that the key factor that is crucial to a crisis is an organizational error. Secondly, $60 \%$ of the companies point out that such a factor is a technical error, and third human error and others. (20\%).

On the question, "What are the factors for escalating organizational crises?" The main factor for the escalation of the crisis, according to $80 \%$ of the companies, is a mistake of the management. The second is the market situation with a relative share of respondents $60 \%$. Third $(20 \%)$ indicates otherwise as a factor for the escalation of crises.

In response to the question, "Is there a need to raise the culture of dealing with crisis situations?", $60 \%$ of the respondents indicated yes rather than $40 \%$ - rather not.

Interesting are the answers to the issue of reporting to the media on a crisis situation. All respondents believe $(100 \%)$ that it is not necessary and they have indicated not. 
To the question "How does the behavior of employees change during a crisis?" Most of the companies (60\%) said that in a crisis the employees are getting together. According to others $(20 \%)$ in crisis, employees fully support the management's decision. Some companies believe employees are looking for a crisis (their relative share is 20\%).

Responding to the question "What are the barriers to more efficient management of organizational crises?" The answers are very varied. Undoubtedly, for all companies surveyed, the barrier to more efficient management of organizational crises is the first budget restriction. Secondly, there is a lack of completeness of the documentation (80\%). Another part of the companies (20\%) believes that the barrier is insufficient management support and insufficient preventative measures. To the question "Which approaches are your company targeting crisis prevention?" Most companies $(80 \%)$ point out that they use past experience to prevent crises. The share of companies (60\%), which use the qualitative and quantitative improvement of activities, is also big. Another part relies on training and qualification courses (40\%). Relatively small relative share of companies (20\%) indicated that they are focused on the personalities of the employees and the managers. There is also the relative share of those who believe that improving organizational communication will prevent crises.

In the event of a crisis when the functional organizational mechanism is obstructed, priority should be a quick recovery of efficiency.

Survey 2. Planning for organizational crises is composed of ten questions, for each indicator the answer is yes / no. Each of the companies has responded to each of the ten questions. The results show that less than half (40\%) surveyed indicate that the company's management supports crisis planning activity and that $60 \%$ think the opposite. This indicates that fewer respondents believe they were prepared for a crisis and $60 \%$ had no such training. The low level of preparedness is explained by the lack of programs and systematic crisis management planning processes.

To the question "Do you run pre-crisis events in the company?" Only $20 \%$ of companies are doing this.
Action plans for crisis situations exist in $20 \%$ of the companies surveyed.

All companies say they do not have a crisis management team with clearly defined responsibilities.

Interesting is the answer to the question "Is there prepared contact information for key organs?", Where $60 \%$ of the companies have indicated they have one.

A prepared contact list for the media is available to $20 \%$ of the companies.

Most of the respondents have developed communication programs in the company $(60 \%)$.

The responses indicate that companies do not regularly review the Crisis Management Plan.

Asked whether there are trained crises responders, $40 \%$ of companies report that employees have been trained to handle problem situations.

Some companies (40\%) draw attention to the results of the risk assessment. This is a prerequisite for timely measures.

In the present study, we also use Survey 3. Self-assessment of the importance of indicators in dealing with crises. For this purpose, the surveyed companies perform a self-assessment on a five-scale scale of 1 to 5 (1-insignificant, 2-insignificant, 3-neutral, 4-significant, 5significant), company leadership, media, foreign investors and injured users. All surveyed companies point out that the management of the firm is of significant importance to them (predominant evaluation $5)$. Most of the companies ( $80 \%$ ) point out the importance of the role of civil servants (predominant evaluation 5).

The role of the media is significant for $80 \%$ of respondents (predominantly 4).

With respect to foreign investors, $100 \%$ of companies are estimated to have a very small role for them (predominantly 1 ).

Most of the respondents (60\%) have indicated that the role of the victims is significant to them (with a predominant assessment of 4).

\section{CONCLUSIONS}

In conclusion, based on the results of a survey conducted by some construction companies in 
Veliko Tarnovo, we can reason to draw the following conclusions:

1. As a result of the conducted Survey 1 . Management of organizational crises and their causes, the following results can be mentioned: - all respondents are of the opinion that economic mechanisms are being taken to solve current problems;

- the main factors of crisis occurring in the first place according to the surveyed companies is the organizational error, and the second is the technical fault;

- all respondents believe that it is necessary to report to the media on a crisis situation;

- the respondents' opinion on the barriers to more efficient management of organizational crises is united. As such, they indicate mainly the limited budget.

2. From the Survey 2. Planning for organizational crises, the following results were obtained:

- There are different views on the need for planning of organizational crises. Most of the half-surveyed companies do not support planning;

- More than half of respondents indicate that they have prepared contact information for key crisis authorities;

- Most companies say they have developed communication programs.

3. From the Survey conducted 3. The selfassessment of the significance of the indicators in dealing with crises gives us the basis for the following summaries of the obtained results:

- all surveyed companies point out that leadership is essential for them;

- for all companies, the assessment of foreign investors is insignificant.

The effectiveness of crisis management is a real problem for any organization, regardless of the conditions and the sphere of activity and stage of its life cycle. Changes in the conditions of the external and internal environment lead to an imbalance in management mechanisms and to a reduction in their effectiveness. The assessment of an organization's crisis management efficiency needs to be done before the onset of the crisis, based on surveys and analysis of the financial situation dynamics. For effective crisis management, organizations need to know all phases and stages in the overall management process.

\section{REFERENCES}

YORDANOVA D.

1. Gabrovski, R., B. Iliev. Korporativen risk menidzhmant. AI „Tsenov”, Svishtov, 2004, s.25.

2. Georgiev, G. Finansovo-schetovoden analiz na targovskoto druzhestvo. Izd. „ForKom”, Sofia, 2004, s.13.

3. Petrova, R. Sistema na schetovodstvoto i schetovodnia analiz kato instrumentarium za upradvlenie na obshtinite. Sbornik s nauchni publikatsii po nauchnoizsledovatelski proekt za 2014 g. na tema „Usavarshenstvane protsesa na obuchenie po schetovodstvo i finansi", V. Tarnovo, 2015, s. 306-310.

4. Fedorova, A. Э, Yu. A. Tokareva. Antikrizisnoe upravlenie personalom organizatsii. Uchebnoe posobie, Ekaterinburg. Izdatelystvo Uralyskogo universiteta, 2017, s.78.

5. Dubrovski, D. Krizni management in prenova podjetja. Koper: Fakulteta za management, 2004, 37-38.

6. Karanina, E. Optimizatsia protsessa sistematizatsii i otsenki riskov predpriyatia v krizisnыh usloviyah, vestnik Permskogo universiteta, vыр. 4 (7). Эkonomika, razdel IV. Otsenka riskov, 2010.

7. Wang, W. Strategic alignment: a knowledge management approach to crisis management, College of Computing and Information Information Science, 2006; available at: http://sunzi.lib.hku.hk/ER/detail/hkul/38344 18 (accessed 27 July 2019)

8. Paunov, M. Strategii na biznesa. Izd. kompleks UNSS, Sofia, 2012, s.73-74.

9. Mayer, P. Organizations in Crise. Une Perspective Clinique et Analytique.// Gerer et Comprendre, № 28, 2002, p. 84-93.

10.Hamilton, S., A. Micklethwait. Greed and corporate failure. New York: Palgrave Macmillan, 2006.

11.Newton, G. W. Bankruptcy and Insolvency Accounting, Practice and Procedure. New York, 2009.

12.Thornhill, S., Amit, R. Learning about Failure: Bankruptcy, Firm Age and the Resource-Based View. // Organization Science, № 15, 2003, p. 497-509.

13.Altman, E. I., Hotchkiss, E. Corporate Financial Distress and Bankruptcy: Predict and Avoid Bankruptcy, Analyze and Invest in Distressed Debt., New York, p.13.

14.Bibeault, D. Corporate Turnaround: How Managers Turn Losers into Winners! Washington, 1999. 
15.Ivanova, G. Nesastoyatelnostta kato krizisno finansovo sastoyanie $\mathrm{v}$ predpriyatieto: simptomi, faktori i stadii na razvitie; available at: <https://www.researchgate.net/publication/ 312025285> (accessed 27 July 2019)

16.Raykov, Z. PR Tehnologiyata na uspeha. „Darmon”, Sofia, 2003, s.73-75.

17. Atali, Zh. Da otseleem v krizite. Riva, Sofia, 2011, s. 64-66.

18. Andreeva, D. Kontseptsia za upravlenie na predpriyatiyata $\mathrm{v}$ kriza, sp. Ikonomicheski alternativi, broy 2, 2010.
YORDANOVA D.

19.PAS 200:2011: crisis management Guidance and good practice.

20.Sabelfeld, T. V., Shavandina, O. A. Analiz podhodov i metodov diagnostiki krizisnogo sostojanija predprijatija. Polzunovskij vestnik, №3, 2006, p.185-190.

21. Yordanova, D. Vazmozhnosti za efektivno upravlenie na organizatsionni krizi. Izd. IVIS, V. Tarnovo, s.142-149.

22.Stefanov, Ts. Pazarna strategia i izgrazhdane na firmenata konkurentosposobnost $\mathrm{v}$ oblast Veliko Tarnovo. Faber, Veliko Tarnovo, 2018, s. 181. 